\title{
Juridical Status of Scientology in European Case Law
}

\author{
Germana Carobene \\ University Federico II, Napoli, Italy
}

\begin{abstract}
The jurisprudential path which led to the legal qualification of Scientology as a religion, according to Italian law was very interesting. The problem concerned the lack of definition of religion and the fact that recognition as a confession gives a religious denomination several benefits such as political taxation. Furthermore, the absence of recognition had led to the possibility of considering normal activities of worship as criminal offenses: i.e. as criminal conspiracy, abuse of the disabled etc. The so-called "long process of Milan", which lasted 20 years, however, officially recognized the characteristics of the religious denomination of Scientology. In this sense, the "Scientology case" can be considered a paradigm for a real understanding of the rights that our legal system recognizes in regards to religious movements and, in particular, the right of religious freedom and the principle of "laicità".
\end{abstract}

Keywords: Scientology, legal qualification, English, Italian and French case law

\section{Preliminary Observations. Recent English Case Law Concerning Scientology}

Religious denominations are not a simple filter between the individual and the State, but stand out as social entities constitutionally recognized and affecting the conduct of the individual ${ }^{1}$. The problem with regard to their qualification is therefore focused on the possibility of acquiring legitimacy in the public sphere. The heterogeneity in the definition of the phenomenology of religion, as it is found in sociological studies, is currently lacking in the legal domain ${ }^{2}$. At the regulatory level, in fact, the conflict only centers on the "dichotomy" between religions and sects where religions are well-structured and socially accepted and, an acceptance is reserved, though differentiated from one country to another, whereas sects, whilst varying are mostly incorporated but have a clear negative connotation ${ }^{3}$.

Germana Carobene, Research, Professor of Ecclesiastical Law and Ecclesiastical organizations and Non-Profit, Department of Political Science, University Federico II.

Correspondence concerning this article should be addressed to Germana Carobene, Mezzocannone 4, 80134, Napoli, Italy.

1 Francesco Finocchiaro, Diritto Ecclesiastico (Bologna: Il Mulino, 2003), 69; Cfr. Danièle Hervieu Léger-Franco Garelli-Salvador Giner-Sebasticin Sarasa-James A. Beckford-Karl Fritz Daiber-Miklos Tomka, La religione degli europei. Fede, cultura religiosa e modernità in Francia, Italia, Spagna, Gran Bretagna, Germania e Ungheria, (Torino: Fondazione Giovanni Agnelli ed., 1992) and www.fga.it/uploads/media/La_religione_degli_europei_01.pdf. Cfr. Peter Harrison, "Religion" and the Religious in the English Enlightenment (Cambridge: Cambridge University Press, 1990); David A. Pailin, Attitudes to Other Religions: Comparative Religion in Seventeenth and Eighteenth-Century Britain (Manchester: Manchester University Press, 1984). Wade Clark-William C. McKinney, American Mainline Religion: Its Changing Shape and Future (New Jersey: Rutgers University Press, 1988). Cfr. also Antony Giddens-Philiph W. Sutton, Sociology, Cambridge, 2013.

${ }^{2}$ Robert N. Bellah, Religious Evolution, in American Sociological Review, vol. 29, 1964, pp. 358-374; John Milton Yinger, Religion in the Struggle for Power: A Study in the Sociology of Religion, (North Stratford: Ayer Publishing, 1946).

${ }^{3}$ Max Bouderlique, Sectes. Les manipulations mentales (Lyon: Chronique Sociale, 1990). Brian R. Wilson, Contemporary Transformations of Religion (London: Oxford University Press, 1976); Brian R. Wilson, Religious sects, (London: Weidenfield and Nicholson, 1970). Brian R. Wilson, The Social Dimension of Sectarism. Sects and New Religious Movements in Contemporary Society (Oxford, Oxford University Press, 1990). 
I would like to focus my brief remarks on the position taken by the jurisprudence in three European countries, Italy, France, and Great Britain, in court cases involving Scientology. The Italian case is the oldest, the Milan process was completed in $2000^{4}$. The other two processes were in 2013. In the English case, the Church of Scientology was recognized as a religious confession, whereas in France, it was convicted of fraud, conspiracy and labelled as a criminal organization ${ }^{5}$. It seems to me that the Italian case can be then viewed as the "trait d'union" between the three processes: in the French process, Scientology was charged with criminal offenses whilst in the British judgment, it was acknowledged and recognized as a religious confession.

As just mentioned, the recent English case in $2013^{6}$ reopened an interesting debate on the concept of religion. It was discussed whether the services performed in the chapel and the performance of a wedding ceremony could be considered as a form of religious worship. The problems faced by the court were inevitably conditioned by the question: whether Scientology should be regarded as a religion.

A complex investigation was then carried out, starting from a well-known case law regarding the Church of Scientology from 1970 which concluded by denying the religious character of the movement, based on a traditional conception of "religion"7.

The Segerdal case arose from a request by the Church of Scientology to have its chapel at Saint Hill Manor, East Grinstead, registered as a place of worship under the Places of Worship Registration Act 1855. Such a status would have entailed tax benefits and other advantages. But the request was rejected by the Divisional Court ${ }^{8}$, and upheld by the Court of Appeal ${ }^{9}$.

With reference to the nature of Scientology, the judge commented:

Turning to the creed of the Church of Scientology, I must say that it seems to me to be more a philosophy of the existence of man or of life, rather than a religion. Religious worship means reverence or veneration of God or of a Supreme Being ${ }^{10}$.

\footnotetext{
${ }^{4}$ Corte di Appello di Milano, Italy, 5 ott. 2000-1 marzo 2001, n. 4780, in Giurispr. Italiana, 2001, with comments of Pasquale Colella, Ancora a proposito di "Scientology", p. 1408 ss.

${ }^{5}$ Cour d'Appel de Paris, 2 febbraio 2012, and, Tribunal Correctionnel de Paris, $12{ }^{\text {ème }}$ chambre, n. 9835623114 c. Association Spirituelle de l'Église de Scientologie, SARL SEL, et autres, del 27 oct. 2009, unpublished. The judgment of the Cour de Cassation 2013, in Cass. crim., 16 oct. 2013, n 12-81.532, 05-82.121, 05-82.122, 03-83.910: Juris Data $\mathrm{n}^{\circ}$ 2013-022379.

${ }^{6} \mathrm{R}$ (on the application of Hodkin and another) v Registrar General of Births, Deaths and Marriages [2013] UKSC 77, 11 December 2013, from http://www.supremecourt.gov.uk/decided-cases/docs/UKSC_2013_0030_Judgment.pdf.

${ }^{7}$ R v Registrar General, ex parte Segerdal [1970] 2 QB 697.

${ }^{8}$ Lord Parker CJ , Ashworth e Cantley JJ, [1970] 1 QB 430.

${ }^{9}$ Court of Appeal, Lord Denning MR , Winn e Buckley LJJ [1970] 2 QB 697. From this court case, it has been formulated the definition of religion in England: cfr. Russel SANDBERG, Law and Religion, Cambridge University Press, Cambrige, 2011, pp. 44-45. About the historical approach v. Julian RIVERS, The Law of Organized Religions: Between Establishment and Secularism, Oxford University Press, Oxford, 2010.

${ }^{10}$ R. v Registrar General, Segerdal and another, in All England Law Reports, [1970] 3 All ER "I do not find any such reverence or veneration in the creed of this church, or, indeed, in the affidavit of Mr. Segerdal. There is considerable stress on the spirit of man. The adherents of this philosophy believe that man's spirit is everlasting and moves from one human frame to another; but still, so far as I can see, it is the spirit of man and not of God. When I look through the ceremonies and the affidavits, I am left with the feeling that there is nothing in it of reverence for God or a deity, but simply instruction in a philosophy. There may be belief in a spirit of man, but there is no belief in a spirit of God. This is borne out by the opening words of the book of ceremonies. It states: In a Scientology Church Service we do not use prayers, attitudes of piety, or threats of damnation. We use the facts, the truths, the understandings that have been discovered in the science of Scientology. That seems to me to express the real attitude of this group. When Mr. Segerdal in his affidavit uses the word 'prayer' he does not use it in its proper sense, i.e. intercession to God. When the creed uses the word 'God' (as it does in two places) it does not use it in any religious sense. There is nothing which carries with it any idea of reverence or veneration of God. The sample sermon has no word of God in it at all. It says that man has a body, mind and spirit. It emphasises man, and not God. It seems to me that God does not come into their scheme of things at all. I do not think that this evidence is sufficient to bear out the contention that this is a place of meeting for religious worship”.
} 
This precedent was considered of paramount importance for the evolution of the issue. In 1974, the Immigration Appeal Tribunal, drawing on the Segerdal case, ruled that Scientologists could not take advantage of the privileges granted in the immigration law to ministers of religion.

As late as 1980, it was used to propose a definition of religion in the case Re South Place Ethical Society. The Society, interested in the "study and dissemination of ethical principles and the cultivation of a rational religious sentiment” had applied for the status of charity, qualifying as a religious organization. Judge Dillon referred to the comments of the Segerdal case on what constituted a religion and noted that religion "is concerned with man's relations with God, and ethics are concerned with man's relations with man. The two are not the same, and are not made the same by sincere inquiry into the question: "what is God?” Religion was then defined as something requiring "faith in a God and worship of that God", which is the definition in English common law.

The definitions of Dillon and Segerdal were also still of fundamental importance in 1999, when the Charity Commission decided to reject the Scientology's application for obtaining the status of a charity. The Commission concluded that the Church had not been established for the advancement of religion, because though "it is accepted that Scientology believes in a Supreme Being”, "the core practices of Scientology, being auditing and training, do not constitute worship as they do not display the essential characteristic of reverence or veneration for a Supreme Being”.

It is clear, however, that the definition developed by the Segerdal judgment in relation to religious worship was a theistic definition of religion, anchored in anachronistic parameters. It is also well-known that in English law, religion and rights share common characteristics. The law protects charitable trusts if the funds are directed towards the advancement of religion ${ }^{11}$. At the individual level it is recognized that individuals have the right to freedom of thought, conscience and religion under Article 9 of the European Convention. They have also the right of non-discrimination on the grounds of religion or belief, in accordance with EU Council Directive 2000/78/EC and in accordance with national legislation based on the principle of equality.

There has never been a universal legal definition of religion in English law, and experience across the common law world over many years has shown the pitfalls of attempting to attach a narrowly circumscribed meaning to the word. There are several reasons for this - the different contexts in which the issue may arise, the wide variety of world religions, the development of new religions and religious practices, and ongoing developments in the common understanding of the concept of religion owing to cultural changes in society.

In order to settle the question posed by the Church of Scientology, the London courts found it necessary to perform a parallel examination of some foreign jurisprudence. Attention focused on two cases, one in the United States and the other one in Australia ${ }^{12}$.

In the first, Malnak v. Yogi, the issue was whether teaching in a public school of a course named the "Science of Creative Intelligence-Transcendental Meditation" constituted a religious activity violating the

\footnotetext{
${ }^{11}$ In Re South Luogo Society Ethical [1980] 1 WLR 1565, 1572, a case on the law of charity, Dillon J said that religion requires "the belief in a god and worship of that god," citing the definition of Buckley LJ of religious worship, already contained in the judgment Segerdal. More recently, the Parliament granted the partial definitions of religion in Section II of the Charities Act 2006 (now Article 3 of the Charities Act 2011) and section X of the Equality Act 2010 for the purposes of such acts. For the purposes of charity law, section 3 (2) (a) of the Charities Act 2011 hours states that: “'Religion' includes-(i) a religion which involves belief in more than one god, and (ii) a religion that does not involve belief in a God”.

${ }^{12}$ The judgment of CJ Adams v. Yogi Malnak 592 F.2d 197 (1979), in a concurring opinion to curiam of the Court of Appeals of the United States, 3rd Circuit, and the judgment of the High Court of Australia, in the Church of the New Faith v. comr of Pay-Roll tax (Victoria) (1983) 154 CLR.
} 
first amendment of the US Constitution. The judge took a different approach compared to previous cases ${ }^{13}$, (where a stricter theistic definition of religion had been adopted), in line with more recent jurisprudence ${ }^{14}$, which meanwhile had moved towards a broader approach in recognition of the fact that adherence to the traditional definition would deny religious identification to the faiths adhered to by millions of Americans.

Judge Adams noted that although the old definition proved no longer to be adequate, no new definition had been fully formed. Instead, the courts had proceeded by a process of analogy, looking at familiar religions as models in order to ascertain, by comparison, whether the new set of beliefs served the same purposes as unquestioned and accepted religions. He observed, however, that there existed a wide difference between deciding "by analogy" that a particular group of ideas constitutes a religion; and explaining what evidence is to be looked at in making such an analogy and justifying it. He identified three kinds of such evidence.

The first was that the system of religious belief is concerned with the ultimate questions of human existence: the meaning of life and death, the role of mankind in the universe, the proper moral code of right and wrong. The second was that the system of belief is comprehensive in the sense that it provides an all-embracing set of beliefs in answer to the ultimate questions. The third was that there were external signs that the belief system was of a kind which could be analogized to accepted religions. Such signs might include formal services, ceremonial functions, the existence of clergy, structure and organization, and attempts at propagation. These kinds of evidence were not to be thought of as a final test for a religion, rather, they were features that recognized religions would typically exhibit.

The significant contribution of the judgment to the development of the jurisprudence in this area lays in Judge Adams's attempt to adopt a comparative approach to the identification of a religion, rather than a traditional definition based on the Judeo-Christian religions ${ }^{15}$.

In the Australian case, the Church of Scientology, according to the Victorian Pay-roll Tax Act 1971, requested an exemption from the tax on wages paid by a religious institution. The question, considered by the High Court, was "whether the beliefs, practices and observances which were established by the affidavits and oral evidence as the set of beliefs, practices and observances accepted by Scientologists, are properly to be described as a religion.” The court held that they were.

The court held that it was to be recognized as a religion, stressing that,

We would therefore hold that, for the purposes of the law, the criteria of religion are twofold: first, belief in a supernatural Being, Thing or Principle; and second, the acceptance of canons of conduct in order to give effect to that belief, though canons of conduct which offend against the ordinary laws are outside the area of any immunity, privilege or right conferred on the grounds of religion. ${ }^{16}$

They therefore concluded that it had been proven that the belief in a Supreme Being was part of Scientology, although there was no Scientology dogma which expressed a particular concept of a Supreme

\footnotetext{
${ }^{13}$ As in the Supreme Court's decision in Davis against Beason 133 US 333 (1890).

${ }^{14}$ Including the decisions of the Supreme Court of the United States v. Seeger 380 U.S. 163 (1965) and Welsh v. United States 398 US 333 (1970).

${ }^{15}$ However, the approach has its flaws. Professor Sarah Barringer Gordon has identified them in the Spirit of the Law: Religious Voices and the Constitution in Modern America (2010), p 150, where he noted, "has invested an extraordinary power in the judiciary to decide where religion begins and ends life secular” and this created uncertainty as to the category of religion unstable. Professor Gordon has provided a larger critical in a chapter entitled The New Age and the New Law: Malnak v. Yogi and the definition of religion in Constitutional Law in a multi-author book of religion and Stories of Law (2010), edited Professor Leslie Griffin. In it he described the decision as influential, but controversial and now a bit "dated".

${ }^{16}$ Their conclusion was critical, p. 136.
} 
Being, and that members of Scientology accepted and followed its practices because they perceived them as a means to give effect to their supernatural beliefs. As a result, Scientology had met the two criteria that had been previously identified.

In light of these important references to law cases, the English courts decided to carry out a review of the traditional dogmatic approach of the concept of religion, as it had been formulated in the Segerdal case. They thus attempted to identify the elements that characterize a "religion”, referring especially to the United States judgment ${ }^{17}$. It was then stressed that,

One of the more important indicia of 'a religion' is that the particular collection of ideas and/or practices involves belief in the supernatural, that is to say, belief that reality extends beyond that which is capable of perception by the senses. If that be absent, it is unlikely that one has 'a religion'. Another is that the ideas relate to man's nature and place in the universe and his relation to things supernatural. A third is that the ideas are accepted by adherents as requiring or encouraging them to observe particular standards or codes of conduct or to participate in specific practices having supernatural significance. A fourth is that, however loosely knit and varying in beliefs and practices adherents may be, they constitute an identifiable group or identifiable groups. A fifth, and perhaps more controversial, indicium (cf Malnak v Yogi) is that the adherents themselves see the collection of ideas and/or practices as constituting a religion. ${ }^{18}$

They, however, added that none of these criteria are necessarily decisive of the question whether a particular collection of ideas and/or practices should be characterized as religion. The assessment must be based on case observation but there is no doubt that the most recent jurisprudential decisions provide an expansion of the concept of religion, beyond the Segerdal case decision and conclude, more correctly, that Scientology satisfied all five criteria that had been identified.

Unless there is some compelling reason to support the contrary, the concept of religion cannot be confined to religions that recognize a supreme divinity. This would be a form of religious discrimination unacceptable in today's society, leading to exclusion of Eastern beliefs, now commonly included as "religions": for example, Buddhism as well as Jainism, Taoism, Theosophy, and part of Hinduism $1^{9}$.

The motivations of the English judgment appear, therefore, absolutely compatible with and overlapping Italian case law and doctrine already largely developed in the nineties. It was, in fact, possible in the past to anchor the definition of "religion" to the existence of a transcendent God; but the knowledge of Eastern religions has made this traditional approach anachronistic and outdated. It calls, therefore, for a new definition, more realistically responsive to changing social needs.

In March 2016, a Belgian Court has cleared the Church of Scientology on charges of forming a criminal organization over alleged fraud. The Brussels Court, after a period of investigation that lasted about 20 years, declared inadmissible all the charges (fraud, extortion, and violation of privacy), against the Church and rejected the request of the religious organization's dissolution.

Also this latter process much recalls the arguments developed by the Italian Courts.

\footnotetext{
${ }_{17}^{17}$ As formulated in the judgment of Mason A. C. J. and Brennan J., p. 130.

${ }^{18}$ P. 174.

19 The evidence in this case shows that, among others, Jains and Buddhists, Theosophists have places of worship registered in England. Lord Denning in Segerdal [1970] 2 QB 697, 707 recognized that the Buddhist temples have been "properly described as meeting places for religious worship," but he referred to them as "exceptional cases” without further explanation. The need to make an exception for Buddhism (which has also been applied to Jainism and Theosophy), and the absence of a satisfactory explanation for this, they are strong signals that there is something not adhering to the general rule supposed.
} 


\section{The Long Italian Process}

In this sense, the long process of Milan is of great importance, which, after six different court decisions was concluded in 2000 and legally recognized Scientology as a religion in Italy. The case was based on a series of criminal charges against some members of the church: conspiracy, fraud, extortion. After some contradictory rulings, the Milan judges became aware of the need to define the religiosity of the movement, i.e. that it should be considered as a religion if all the stated activities were qualified as normal religious practices.

The judgment of the Supreme Court in 1995 is of fundamental importance; it determined, for the first time and in a decisive manner, the need to assess the religious nature of an association which in turn related to and challenged any assessment under criminal law ${ }^{20}$.

It is, then, only from this standpoint that the problem focused on the religiosity of the movement as a sine qua non for the qualification of possible offenses under the criminal law, arising from the actions of the group. This recognition has an indirect effect with respect to the violation of the criminal law: if a movement has a religious nature it cannot be qualified as criminal ${ }^{21}$.

The judgment noted that if a group defined itself as a religious confession, the Court has the obligation to check by referring, in the absence of a legislative definition, to the criteria laid down by the Constitutional Court in $1993^{22}$. The Constitutional Court had specified that, in the absence of an agreement with the Italian state, and in order to recognize the confessional character of a movement, it can refer to some guidelines: previous public recognition, statutes of the institution, common consideration. It, however, pointed out the partiality of these criteria through the use of the adverb "also", not excluding therefore, a greater scope for interpretation and it is for this reason that the articles of the Statutes of the association must be subjected to an thorough investigation, necessary for assessing whether the articles are actually applied.

The application of these rules of interpretation is vital in identifying if the goals expressed by the statutes are "religious" though one could also argue the difficulty of differentiating this element from self-qualification, as it has been stressed in the judicial rulings. For a correct formulation of the problem, it is therefore necessary to verify the purposes set out in the statutes in order to control the degree of compliance with the activities actually carried out.

In this case, to understand the structure of the religious movement was absolutely necessary, not only for the assessment of tax crimes but also for the contestation of the crime of association, because once Scientology had been granted the nature of a religious belief, it could no longer be convicted of conspiracy, unless those belonging to the confession had changed by mutual agreement the statutory articles, giving rise to a new purpose, different from the original.

The qualification of a religious movement is to be assessed according to nationally established criteria, in the light of the constitutional principle of religious freedom which is subject to well-defined limits: these being the fundamental limitations that constitute the essential conditions for the achievement of a peaceful

\footnotetext{
${ }^{20}$ Corte di Cassazione, II sez. penale, n. 5838, 9 febb. 1995, Cass. Pen., 1996, 3, pp. 2520-2528, with comments of Rocco Blaiotta, Scientology: una religione al cospetto della legge, pp. 2528-2536. V. also Germana Carobene, Scientology tra religione $e$ sanzione (Napoli: Liguori, 2012).

${ }^{21}$ Corte di Cassazione, n. 5838, 1995, cit., p. 20.

${ }^{22}$ Corte Costituzionale, 27 aprile 1993, n. 195 in Foro It., 1994, I, 2986 ss. with comments of Nicola Colaianni, Sul concetto di confessione religiosa; Giuseppe Casuscelli, Ancora sulla nozione di "confessione religiosa": il caso Scientology, in Quad. dir. pol. eccl., 1998, 3, p. 809 ss.; Riccardo Acciai, La sent. n. 195 del 1993 della Corte Costituzionale e sua incidenza sulla restante legislazione regionale in materia di finanziamenti all'edilizia di culto, in Giur. cost., 38, 1993, pp. 2151-2165; Giovanni Di Cosimo, Alla ricerca delle confessioni religiose, in Dir. eccl., 1998, 1, p. 421 ss.
} 
coexistence of individuals in the society, the limits that are imposed by civilization itself and relevant essential values and constraints; furthermore there is a general limitation, pursuant to art. 19 of the Constitution, "morality"

In subsequent case law ${ }^{24}$, in the same process, it was emphasized that in the absence of a definition of religion, it is very difficult - to ascertain if a group of people calling themselves a religious movement do have such quality. The Constitution had opted for an extended concept of religion, as it is apparent from the choice of not using, in Article 8 of the Constitution, the noun "religion" but the term "confessione religiosa" which identifies, on a philological dimension, a group characterized by a common profession of faith ${ }^{25}$. Two important considerations should be borne in mind: the Buddhist Agreement where the Italian State recognized as a confession a religious movement that does not presuppose the existence of a Supreme Being and the treaty of friendship with the U.S.A. that requires qualifying as a religion any movement which is already so recognized as such in the United States ${ }^{26}$.

By examining specific statutes and their implementation as a religious practice, it is clear that any religion, including Christianity, implements high levels of purification and ascetic techniques which, whilst they cannot claim to be scientific, do enjoy some objectivity ${ }^{27}$. Most of the Italian case law and legal commentary conclude today that faith in the identity of a Supreme Being cannot be considered the only element concerning the idea of "religion"28.

From the examination of the judicial process, there is clearly a significant importance given to the principle of the effectiveness of self-qualification (a necessary, but not sufficient condition for a religious group to be called a religion is to auto -qualify itself as a "religion”). The direction taken by Italian jurists seems, therefore, prone to a kind of recognition based on the inductive method rooted in self-qualification. The end of this long and complex process ended with the judgment of the Court of Appeal of Milan, 5 October $2000^{29}$.

As it has been pointed out in the judgment, the statutes of the Church of Scientology clearly defines the religious aims of the association: the healing of the spiritual needs of the faithful, through individual and collective rituals; the treatment and protection of organizations that preach and practice the religion of Scientology; the establishment of training centers for the teaching and dissemination of the religion, the promotion and encouragement of the development of the Scientology religion and its rituals ${ }^{30}$.

The impossibility of defining in a rigid and unchangeable manner the concept of religious phenomenon linked to the evolution of forms of religiosity in different space-time coordinates is once again reiterated here. All religions were created by a slow evolutionary process that progressively delineated their structure, dogmas

\footnotetext{
${ }^{23}$ Corte Cassazione, n. 5838, 1995.

${ }^{24}$ Cassazione penale, sez. VI 8-22 ottobre 1997, n. 1329, in Quad. dir. pol. eccl., 1998, 3, pp. 836-850. Cfr. RocCo BlAIOTTA, La Suprema Corte ancora su Scientology, organizzazioni religiose ed organizzazioni criminali, in Cass. Pen., 1998, 9, p. 2384 ss.

${ }^{25}$ Corte di Cassazione, n. 1329, 1997, p. 29.

${ }^{26}$ Treaty of 2 feb. 1948, implemented in 1948 with L. June 18, 1949, 385. Articles I.2 and II. 1.2.3. allows Scientology to do with this qualification in Italy.

${ }^{27}$ Corte di Cassazione, n. 1329, 1997, cit., p. 42.

${ }^{28}$ Massimo Jasonni-Maria Vittoria Galizia, La legittimazione giudiziaria di una confessione religiosa. Il caso Scientology alla luce dei più recenti indirizzi della Corte di Cassazione, in Diritti e Diritti, 19 ottobre 2000, p. 3 ss. It’s important also to observe that "tutto il sistema di sostegno (normativo e fiscale) verso tali forme di partecipazione attiva si basa sulla meritevolezza degli scopi perseguiti in quanto tradotti nel compimento di opere a vantaggio dell'intera collettività”: Antonio Fuccillo, Dare etico. Agire non lucrativo, liberalità non lucrative e interessi religiosi (Torino: Giappichelli, 2008), 15.

${ }^{29}$ Corte di Appello di Milano, 5 ott. 2000-1 marzo 2001, n. 4780, in Giurispr. Italiana, 2001, with comments of Pasquale Colella, Ancora a proposito di "Scientology", both p. 1408 ss.

${ }^{30}$ Cfr. also Giuseppe Casuscelli, Ancora sulla nozione di “confessione religiosa”..., cit., pp. 834-835.
} 
and rituals, and, with reference to Scientology, the fact that its statutes have explicitly assumed these characteristics only in recent decades, cannot act as a reason for denying its religious nature.

\section{The Condemnation of the Religious Movement in France. Conclusion.}

A recent condemnation of Scientology in France, which was confirmed by the Supreme Court in October of 2013, more clearly revealed, however, the problems relating to the protection of individual freedom, within EU structures, and in particular the membership of new groups of a religious nature ${ }^{31}$. The Court has, in fact, confirmed the sentences-for conspiracy to fraud and illegal pharmaceutical practice-not only against five Scientologists, but also against the two main French organization structures: the Scientology Celebrity Centre and Bookstore.

The case dates back to 1998, when some individuals accused the Church of having persuaded them to spend significant sums of money on Church services using the personality test to bring them into the Church.

There are strong similarities to the Italian case, but the two case laws followed completely different paths. In France, the judges avoided any definition of religion, whereas Italian lawyers thought it to be a necessary condition for any evaluation, real and concrete, about the movement and its possible dangers.

In the case, in question the prosecution focused on the personality test, with the exclusion of other "tools" used by the Scientology religion: E-meter, Purification Rundown, religious counseling, etc. The Court held that the fraudulent nature of the test is deduced from the scientific presentation of the same, which is used by people without any training in psychology. The judgement noted that individuals using a philosphica or religious doctrine, which has a lawful purpose, to intentionally deceive third parties for financial or commercial ends, are liable to prosecution for the offence of fraud. The exercise or practice of a religion may therefore lead to certain members of the religious association undertaking deceptive manoeuvres the aim of which is to deceive bona fide third parties. The assessment of such deceptive manoeuvres undertaken through the alleged practice of religion does not imply a value judgement on the doctrine professed by the religious association, it considers only the lawfulness of the methods used. ${ }^{32}$

It is important to reiterate that these problems stem from a misinterpretation of the relationship between religion and "sect" and the possible phenomena of deviance related to the latter. The French court incorrectly set the criteria; by emphasizing the uselessness of qualifying Scientology as a legal entity, whereas such failure of classification led to the absurdity of having to assess the scientific nature of an instrument which is simply "confessional". The investigation into the alleged or real scientific validity of an instrument this being a purely religious one-cannot be analyzed with tools of a scientific investigation, because it is related to a phenomenon linked to faith and the irrational.

In the juridical formulation of the offense of fraud, the demonstration of the intentional element is crucial. However, being a faithful believer of the doctrines of Scientology could not be invoked as an exception, according to the Paris judges.

The notion of "fraud" is also difficult to identify, especially with regard to a sect. The protection of the adult is a particularly sensitive issue, especially if not referred to in the context of protecting the physical or

\footnotetext{
${ }^{31}$ Gemana Carobene, Le minoranze religiose tra normativa penale e diritti di libertà: rilievi a margine di una recente sentenza su Scientology, in www.statoechiese.it, juin 2010; Susan Palmer, The New Heretics of France. Minority Religions, la République and the Governement-Sponsored "War on sects" (Oxford: Oxford University Press, 2011).

${ }^{32}$ Court of Paris, 2009, cit., p. 85.
} 
financial position of the subject, but in relation to her/his psychological integrity, which is, by definition, a very vague concept. We run serious risk in qualifying any action lacking scientific meaning as fraudolent activity, something that is a common element in all religions in any coordinate space-time ${ }^{33}$ !

It should, therefore, be demonstrated that the test is perceived as "deceptive" in a subjective manner, but the Scientologists use it not only as one of the instruments of proselytism but also for themselves, as an indicator of development along their religious path. It is, also, and it is appropriate to repeat, little more than a means of access to the confession, and not the only means of progression in this religion. It is one of the modes of religious proselytism, free of charge, which may induce individuals to question themselves and can direct them towards Scientology. The test is, in fact, integrated into the practice of the teachings of Hubbard and has the objective of measuring the personality, the level of self-awareness and success in life. Since it is a spiritual center- even assuming that the subjects do not know they are being confronted with a religion in the common sense of the word-there is no doubt that they cannot expect the scientific approach of psychological or psychotherapeutic practices, but that they would receive spiritual or metaphysical assistance.

Another alleged offense is that of conspiracy. This offense also requires proof of an intention, prior to the preparation of the crime which, to be punishable, must be characterized by one or more material facts ${ }^{34}$. In the case in question, it should be proven that, the basis of the activities of Scientology in France is not religious but fraudulent acts, concerted by the group ${ }^{35}$.

The offenses are therefore the same as those alleged in the Italian case, but profoundly different is the legal and political context of the two countries. In Italy, the crime of plagio (or mental manipulation) has been decriminalized since $1981^{36}$, while in France, in 1996, a parliamentary committee drafted a report on sects, including Scientology among them ${ }^{37}$, and in 2001 the law was passed against sectarian movements and mental manipulation $^{38}$. The different legal framework and policy interventions have affected the assessment of the case.

Let me conclude by emphasizing that the issues raised by these judgments are of particular interest to the jurist as, in the study of contemporary religious groups, one of the most difficult problems is the approach to these movements with the appropriate theoretical framework ${ }^{39}$. The current social issues, arising from "religious groups" not formed according to traditional rules, requires the lawyer to deal with this phenomenon

\footnotetext{
${ }^{33}$ Cfr. Dionisio Llamazares Fernandez, Sectas y Derecho fundamental de libertad religiosa, in Juan Goti Ordenana, Aspectos socio-juridicos de las sectas desde una perspective comparada, Onati proceedings, 5, 1991.

${ }^{34}$ L'art. 132-71 c.p. stressed that "constitue une bande organisée tout groupement formé ou toute entente établie en vue de la préparation, caracterisée par un ou plusieurs faits matériels, d’une ou plusieurs infractions”.

${ }^{35}$ Les sectes et le droit en France, Francis Messner (ed.), (Paris: PUF, 1999); Luis Martínez-Villaseñor González de Lara, Mari Luz Collado Caño,Arancha Amorós Busqueras, Concepto jurídico de secta, in Derecho y Opinión, 2, 1994, pp. 25-36. Richard Friedli, Essai sur le concept de 'secte': un critère 'bonne santé-maladie', in Conscience et liberté, 1999, pp. 21-47.

${ }^{36}$ The judgment of Italian Constitutional Court, 8 juin 1981, n. 96, was published in Giust. pen., 1981, I, c. 226 ss.; in Riv.it. dir.proc.pen, 1981, p. 1147 ss. with comments of Marco Boscarelli, A proposito del "principio di tassatività", p. 1147 ss.; in Giur. Cost., 1981, p. 806 ss. with comments of Paolo G. Grasso, Controllo sulla rispondenza alla realtà empirica delle previsioni legali di reato, p. 808 ss.; in Dir. famiglia e delle persone, 1982, p. 311 with comments of Francesco Dall'Ongaro, L'illegittimità costituzionale del reato di plagio, p. 311 ss. On line http://www.giurcost.org/decisioni/1981/0096s-81.html.

${ }^{37}$ Alain Gest-Jacques Guyard, Les sectes en France, La Documentation française, coll. Dossier d'information de l'Assemblée Nationale, 1996, e in xenu.com-it.net/txt/guyard.htm.

${ }^{38}$ Loi 2001-504 del 12 juin 2001 tendant à renforcer la prévention et la répression des mouvements sectaires portant atteinte aux droits de l'homme et aux libertés fondamentales, in Journel Officiel, 13 juin 2001, p. 9337. Germana Carobene, Il binomio laicità-libertà religiosa nel sistema francese ed in quello italiano di fronte alle problematiche dei nuovi movimenti religiosi, in Il Diritto Ecclesiastico, 2004, 3, pp. 699-720.

${ }^{39}$ James A. Beckford-James T. Richardson, A Bibliography of Social Scientific Studies of New Religious Movements, in Social Compass, XXX, I, 1983, pp. 111-135.
} 
in a careful manner and to avoid, first, the construction of a completely open system-easy prey to exploitation — and secondly, to impose what has become an obsolete legal framework. The management of diversity — cultural and religious-is, in fact, one of the major challenges of our time, especially in our democratically structured societies. The novelty in this contemporary world is the rise of the politics of identity, the result of a mature theoretical awareness, linked to the inability of managing modern social dynamics according to obsolete patterns of inclusion/exclusion ${ }^{40}$.

\section{References}

Acciai, R. (1993). La sent. n. 195 del 1993 della Corte Costituzionale e sua incidenza sulla restante legislazione regionale in materia di finanziamenti all'edilizia di culto. Giurisprudenza costituzionale, 38, 38, 2151-2165.

Beckford, J. A., \& Richardson, J. T. (1983). A bibliography of social scientific studies of new religious movements. Social Compass, $X X X, I, 111-135$.

Bellah, R. N. (1964). Religious evolution. American Sociological Review, 29, 358-374.

Blaiotta, R. (1998). La Suprema Corte ancora su Scientology, organizzazioni religiose ed organizzazioni criminali. Cassazione Penale, 9, 2384.

Carobene, G. (2004). Il binomio laicità-libertà religiosa nel sistema francese ed in quello italiano di fronte alle problematiche dei nuovi movimenti religiosi. Diritto Ecclesiastico, 3, 699-720.

Carobene, G. (2010). Le minoranze religiose tra normativa penale e diritti di libertà: Rilievi a margine di una recente sentenza su Scientology. Statoe Chiese, www.statoechiese.it, 1.

Casuscelli, G. (1998). Ancora sulla nozione di "confessione religiosa”: Il caso Scientology. Quaderni Diritto Politica Ecclesiastica, 3, 809.

Colaianni, N. (1994). Sul concetto di confessione religiosa. Foro It., I, 2986.

Colella, P. (2001). Ancora a proposito di “Scientology”. Giurispr. Italiana, 1408.

Di Cosimo, G. (1998). Alla ricerca delle confessioni religiose. Diritto ecclesiastico, 1, 421.

Friedli, R. (1999). Essai sur le concept de “secte”: Un critère "bonne santé-maladie”. Conscience et Liberté, 21-47.

Jasonni, M., \& Galizia, M. V. (2000). La legittimazione giudiziaria di una confessione religiosa. Il caso Scientology alla luce dei più recenti indirizzi della Corte di Cassazione. Diritti e Diritti, 3.

Llamazares Fernandez, D. (1991). Sectas y Derecho fundamental de libertad religiosa, in Goti Ordenana, J. Aspectos socio-juridicos de las sectas desde una perspective comparada, Onati proceedings, 5.

Martínez L., Villaseñor González de Lara, Collado Cano M. L., Arancha Amorós Busqueras. (1994). Concepto jurídico de secta. Derecho y Opinión, 2, 25-36.

Bouderlique, M. (1990). Sectes. Les manipulations mentales. Lyon: Chronique Sociale.

Carobene, G. (2012). Scientology tra religione e sanzione. Napoli: Liguori.

Clark, W., \& McKinney, W. C (1988). American mainline religion: Its changing shape and future. New Jersey: Rutgers University Press.

Colaianni, N. (2006). Eguaglianza e diversità culturali e religiose. Un percorso costituzionale. Bologna: Il Mulino.

Ferrari, S. (2002). Lo spirito dei diritti religiosi. Bologna: Il Mulino.

Fuccillo, A. (2008). Dare etico. Agire non lucrativo, liberalità non lucrative e interessi religiosi. Torino: Giappichelli.

Gest, A., \& Guyard, J. (1996). Les sectes en France. La Documentation française, coll. Dossier d' information de l’ Assemblée Nationale.

Giddens, A., \& Sutton, P. W. (2013). Sociology 7. Cambridge: Polity Press.

Harrison, P. (1990). "Religion” and the religious in the English enlightenment. Cambridge: Cambridge University Press.

Messner, F. (Ed.). (1999). Les sectes et le droit en France. Paris: PUF.

\footnotetext{
${ }^{40}$ Silvio Ferrari, Lo spirito dei diritti religiosi (Bologna: Il Mulino, 2002); Mario Ricca, Oltre Babele. Codici per una democrazia interculturale (Bari: Dedalo, 2008); Nicola Colaianni, Eguaglianza e diversità culturali e religiose. Un percorso costituzionale, (Bologna: Il Mulino, 2006); the same author, in another passage pointed out that "le religioni affollano l'agorà politica con le loro diverse visioni del mondo, ne diventano componenti culturali, si atteggiano a moral o cultural entrepreneurs con la propria identità da salvaguardare e promuovere. I luoghi di culto vuotati dalla secolarizzazione le spingono a cercar posto nei luoghi pubblici, ad accentuare piuttosto che la credenza, l'appartenenza” (p. 9).
} 
Pailin, D. A. (1984). Attitudes to other religions: Comparative religion in seventeenth and eighteenth-century Britain. Manchester: Manchester University Press.

Palmer, S. (2011). The new heretics of France. Minority religions, la République and the Governement-sponsored "War on sects". Oxford: Oxford University Press.

Ricca, M. (2008). Oltre Babele. Codici per una democrazia interculturale. Bari: Dedalo.

Wilson, B. R. (1970). Religious sects. London: Weidenfield and Nicholson.

Wilson, B. R. (1976). Contemporary transformations of religion. London: Oxford University Press.

Wilson, B. R. (1990). The social dimension of sectarism. Sects and new religious movements in contemporary society. Oxford: Oxford University Press.

Yinger, J. M. (1946). Religion in the struggle for power: A study in the sociology of religion. North Stratford: Ayer Publishing. 